\title{
EKSISTENSI PASAR TRADISIONAL DI TENGAH PERSAINGAN DENGAN PASAR MODERN DI KABUPATEN BULELENG
}

\author{
Ni Made Nopi Ariani, Stevie Putriadi, Adik Diantini, Erfina Fitriani, I Putu Gede \\ Handi Junio, Ketut Eny Suastini \\ Jurusan Akuntansi, Universitas Pendidikan Ganesha, Singaraja, Bali, Indonesia
}

\begin{abstract}
Abstrak
Penelitian ini bertujuan untuk mengungkap bagaimana kontribusi pasar tradisional terhadap APBD Kabupaten Buleleng, bagaimana kondisi pasar tradisional saat ini, apa tanggapan masyarakat terhadap kondisi pasar tradisional dengan adanya pasar modern saat ini, serta upaya pemerintah ( PD Pasar) dalam menanggulangi masalah - masalah yang dihadapi pasar tradisional akibat adanya pasar modern dalam mempertahankan eksistensinya. Penelitian ini tergolong penelitian bertipe kualitatif dengan teknik pengumpulan data wawancara dan dokumentasi. Hasil penelitian menunjukkan bahwa 1) kontribusi pasar tradisional sangat besar bagi APBD dalam bentuk retribusi seperti uang parkir (karcis kendaraan), sewa tanah, pungutan harian, dan pendapatan lainnya; 2) secara umum masyarakat menilai keberadaan pasar tradisional masih berpotensi dengan keunggulan harga di pasar tradisional yang lebih terjangkau namun keberadaan fasilitas yang ada di pasar tradisional kurang terjaga kebersihannya serta fasilitas yang kurang memadai; dan 3) untuk menanggapi respon masyarakat mengenai kondisi fisik pasar yang masih kurang baik, adapun upaya yang dilakukan oleh PD.Pasar sendiri meliputi renovasi dan revitalisasi pasar.
\end{abstract}

Kata kunci: pasar tradisional; pasar modern; kontribusi pasar

\begin{abstract}
This study aims to reveal how traditional markets contribute to the Buleleng Regency APBD, how the current traditional market conditions are, what are the people's responses to the conditions of traditional markets with the current modern market, and the government's efforts (PD Pasar) in overcoming the problems faced by the market traditionally due to the existence of a modern market in maintaining its existence. This research is classified as a qualitative research with interview and documentation data collection techniques. The results showed that 1) the contribution of the traditional market was very large for the APBD in the form of fees such as parking fees (vehicle tickets), land rent, daily fees, and other income; 2) in general the community assesses the existence of traditional markets with potential price advantages in traditional markets that are more affordable, but the presence of existing facilities in traditional markets is lacking in cleanliness and inadequate facilities; and 3) to respond to the community's response regarding the physical condition of the market which is still not good, while the efforts made by $P D$. The market itself includes renovation and market revitalization.
\end{abstract}

Keywords: traditional markets; modern market; market contribution

\section{Pendahuluan}

Pasar merupakan sektor yang cukup diperhitungkan dalam tata kelola pemerintahaan. Pasar itu sendiri merupakan salah satu tempat terjadinya transaksi jual beli barang atau jasa antara konsumen dan produsen. Pasar ada berbagai macam klasifikasinya seperti pasar menurut bentuk kegiatannya, pasar menurut cara transaksinya, pasar menurut jenis barangnya, pasar menurut keleluasaan distribusinya. Beragam jenis pasar yang ada, masyarakat pada umumnya mengenal pasar tradisional karena jumlah yang tersebar cukup banyak dan sudah dikenal sejak dulu sebelum ada jenis pasar yang lainnya. Pasar tradisional dapat dikatakan pasar yang paling sederhana. Dalam pasar tradisional tidak terdapat peraturan yang ketat, hanya ada aturan antar pedagang saja. Hal tersebut yang menjadikan mudahnya para penjual masuk dan keluar pasar.

Pasar Tradisional telah ada sejak puluhan abad yang lalu, bahkan pada zaman sebelum masehi. Pada mulanya pasar melakukan transaksi secara barter (tukar menukar barang sesuai keperluan). Kegiatan pasar yang ada di pesisir pantai diramaikan oleh 
pedagang - pedagang dari Cina maupun pedagang dari pesisir selat malaka. Pedagang yang berasal dari pesisir selat malaka menggunakan pasar tradisional sebagai media penyaluran barang dan jasa serta memperluas ekspansi dalam tujuan perkembangan agama. Hingga saat ini Pasar Tradisional bertahan keberadaannya berdampingan dengan masyarakat walau alat transaksinya telah berkembang menjadi uang.

Pasar Tradisional sangat familiar bagi masyarakat, dengan karakteristik yang menciri khas seperti tawar menawar dalam harga barang atau jasa antar pembeli dan penjual sehingga tercipta komunikasi yang baik antar kedua belah pihak. Pasar Tradisional dirasakan sangat penting bagi masyarakat. Karena mayoritas dari masyarakat di Indonesia pada umumnya petani dan nelayan, pasar merupakan media dalam menyalurkan hasil bumi dari masyarakat dan untuk masyarakat kembali. Pasar Tradisional sendiri merupakan implementasi dari ekonomi kerakyatan yang diterapkan oleh bangsa Indonesia. Ekonomi kerakyatan diartikan sebagai sistem perekonomian pelaksanaan kegiatan, pengawasan, dan hasil dari kegiatan ekonomi yang dapat dirasakan oleh seluruh masyarakat.

Manfaat yang dapat dipetik dari berbagai kalangan masyarakat. Baik masyarakat golongan menengah ke bawah maupun menekah ke atas. Berbagai jenis produk ditawarkan, mulai dari bumbu makanan, buah-buahan, lauk-pauk dan segala macam kebutuhan sehari-hari yang dibutuhkan masyarakat dan harganyapun masih terjangkau.

Dalam urusannya dengan keberadaan pasar tradisional dibawah pengawasan dan tuntunan pemerintah sebagai otoritas kebijakan yaitu Dinas Koperasi , Perdagangan dan Perindustrian (Diskopdagrin) dari tingkat pusat hingga daerah. Saat ini jika kita lihat kondisi riil dari Pasar Tradisional khususnya di Kabupaten Buleleng. yang menjadi lokasi penelitian kami, dikelola oleh Perusahaan Daerah Pasar (PD Pasar) Kabupaten Buleleng, berdasar Surat Keputusan (SK) Bupati No.370 Tahun 2004 tentang Penyerahan Aset. SK tersebut berisikan rincian jumlah pasar tradisional yang dikelola oleh PD Pasar sejak tahun 2004 yaitu berjumlah 15 unit pasar yang terdiri dari Pasar Anyar Singaraja, Pasar Mumbul, Pasar Banyuasri, Pasar Buleleng, Pasar Kampung Bugis, Pasar Kampung Tinggi, Pasar Sukasada, Pasar Sangsit, Pasar Bungkulan, Pasar Latri (Sengol), Pasar Tamblang, Pasar Banjar, Pasar DC Seririt, Pasar Seririt, dan Pasar Sanggalangit. Sebelum dikeluarkan SK tersebut jumlah pasar tradisional dibawah PD Pasar ialah 18 unit, dua diantaranya Pasar Kubutambahan, Pasar Pancasari, Pasar Banjar, dan Pasar Sanggalangit sudah diambil alih oleh pengelolaan pihak Desa Adat. Informasi terakhir pada Desember 2016 bahwa jumlah pasar yang dikelola PD Pasar Buleleng ialah 13 unit, dimana Pasar Sangsit telah dikelola Desa Adat-nya.

Walaupun jumlah pasar tradisional berlahan menurun masyarakat masih memilih pasar tradisional sebagai bertransaksi jual beli. Berarti daya saing pasar tradisional terhadap pasar modern masih cukup baik. Namun,pasar tradisional masih dianggap masih kurang baik dari segi fisik seperti kesan kebersihan lingkungan, pelayanan, fasilitas dan keamanan yang masih kurang memadai. Seiring dengan perkembangan zaman, pasar modern terus berkembangkan dari segi pelayanan dan fasilitanya. Jika pasar tradisional tidak mulai meningkatkan kualitasnya maka beberapa tahun kedepan pasar tradisional tidak dapat bersaing dengan pasar modern. Untuk menanggulangi kemungkinan tersebut diperlukan campur tangan pemerintah dalam mengelola pasar tradisional secara baik dan optimal. Dengan kelemahan yang dimiliki diharapkan peran pemerintah untuk mempertahankan eksistensi dari pasar tradisional mengingat pembangunan dan perluasan keberadaan pasar modern yang memiliki tatanan fisik kebersihan yang baik, keamanan, dan fasilitas yang mulai menggunakan teknologi - teknologi yang canggih, yang mampu menarik minat masyarakat. Sehingga pemerintah sebagai lembaga otoritas yang berwenang, memiliki kewajiban untuk mempertahankan keberadaan dan eksistensi dari pasar teradisioanal ditengah persaingan dengan pasar modern itu sendiri.

Maka dari itu kami tertarik untuk melakukan penelitian yang berjudul " Upaya Pemerintah Kabupaten Buleleng Dalam Mempertahankan Eksistensi Pasar Tradisional Ditengah Persaingan Dengan Pasar Modern".

Berdasarkan latar belakang diatas, didapat beberapa rumusan masalah yaitu bagaimana kontribusi pasar tradisional terhadap APBD Kabupaten Buleleng, bagaimana 
kondisi pasar tradisional saat ini, apa tanggapan masyarakat terhadap kondisi pasar tradisional dengan adanya pasar modern saat ini, serta upaya pemerintah ( PD Pasar) dalam menanggulangi masalah - masalah yang dihadapi pasar tradisional akibat adanya pasar modern dalam mempertahankan eksistensinya.

\section{Hasil dan Pembahasan}

Perkembangan pasar tradisional yang ada di Kabupaten Buleleng dibawah pengelolaan dan pengawasan Perusahaan Daerah Pasar (PD Pasar) berdasar Surat Keputusan Bupati (SK.Bupati) Nomor 68 Tahun 2003 serta Perda Nomor 4 Tahun 2005 yang berlaku sejak tahun 2004 sampai dengan sekarang, karena sebelumnya pengelolaan pasar tradisional mulai dikelola sejak tahun 1989 sampai dengan 2003 yang dikelola oleh Dispenda yang dikenal sebagai UPT.Pasar. Menurut Kepala Seksi Sumber Daya Manusia dan Personalia, Drs. Gede Suamba yang ditemui dikantornya menjelaskan bahwa pengelolaan yang dilakukan PD. Pasar dipertegas dengan adanya SK.Bupati Nomor 68 Tahun 2003 serta Perda Nomor 4 Tahun 2005 mendorong pengelolaan yang lebih baik untuk pasar tradisional itu sendiri dengan penjelasan lingkup tugas dan wewenang dari PD.Pasar, dengan memaksimalkan kinerja manajemnen organisasi yang sesuai aturan, beliau menargetkan PD.Pasar dapat menjalankan tugas untuk mengembangkan, mengawasi dan mengelola keberadaan pasar tradisional di Kabupaten Buleleng.

\subsection{Kontribusi Pasar Tradisional Terhadap APBD Kabupaten Buleleng}

Pengelolaan pasar tradisional yang ada di Kabupaten Buleleng telah dilakukan sejak tahun 1989 hingga sekarang tentu memberikan gambaran yang umum kepada masyarakat bahwa keberadaan dari pasar tradisional masih menjadi tanggung jawab pemerintah. Pengelolaan dalam kegiatan fisik pasar maupun non fisik, dimana pengelolaan fisik baik berupa pengelolaan kondisi tempat, bangunan, dan lainnya. Sedangkan dengan pengelolaan non fisik yaitu pengelolaan keuangan, administrasi, dan regulasi pasar tradisional.

Oleh Plt. Kasie Pembukuan, Komang Sonni,SE. pengelolaan yang dilakukan oleh PD.Pasar selama ini tidak dari APBD melainkan dari PD. Pasar sendiri. Yang diperoleh dari pendapatan - pendapatannya dan modal yang berasal dari pinjaman bank. Sehingga pendapatan yang diperoleh PD Pasar berupa setoran (pendapatan) yang terdiri dari pendapatan retribusi (terdiri atas pungutan harian dan sewa tanah) dan pendapatan lainya (terdiri dari pendapatan SP, pendapatan pelimpahan, pendapatan listrik langsung, pendapatan listrik fasum, pendapatan pemeliharaan keamanan, pendapatan jasa giro, penjualan hak pakai tempat usaha, pendapatan iuran kebersihan pasar, pendapatan dari karcis masuk kendaraan, pendapatan WC, pendapatan sewa meja dan kursi, dan pendapatan lain - lain). Dengan pemasukan tersebut pun dipergunakan untuk pembiayaan berbagai pembiayaan pasar - pasar yang ada.

\subsection{Kondisi Pasar Tradisional}

Kondisi pasar tradisional saat ini memang sangat memprihatinkan dimana keberadaannya bersaing dengan adanya pasar modern. Terancamnya keberadaan pasar tradisional menjadi dorongan bagi semua pihak baik pemerintah dan seluruh masyarakat untuk melindungi keberadaan pasar tradisional dengan menggali eksistensi yang dimiliki pasar tradisional. Adapun beberapa aspek yang perlu diperhatikan dalam menggambarkan eksistensi pasar tradisional yang meliputi:

a. Aspek Budaya

Aspek budaya (culture) merupakan bagian tak terpisahkan dari kegiatan manusia dengan lingkungannya, kebudayaan diartikan sebagai suatu kerangka pikiran dan merupakan hasil karya manusia. Izza (2010) menjelaskan bahwa,

Konsep kebudayaan dalam arti yang luas yaitu seluruh total dari pikiran, karya dan hasil karya manusia yang tidak berakar pada nalurinya, karena itu hanya bisa dicetuskan oleh manusia sesudah suatu proses belajar. Konsep kebudayaan akhirnya dipecah lagi dalam unsur - unsurnya guna keperluan analisa konsep kebudayaan. Unsur - unsur 
terbesarnya yang terjadi perpecahaan tahap pertama disebut dengan unsur kebudayaan universal yang hubungannya dengan kehidupan manusia. Unsur - unsur tersebut adalah (1) sistem religi dan upacara keagamaan, (2) sistem organisasi masyarakat, (3) sistem pengetahuan, (4) bahasa, (5) kesenian, (6) sistem pencarian hidup, dan (7) sistem teknologi dan peralatan.

Berdasarkan beberapa konsep kebudayaan yang ada, pemahaman pasar tradisional mengacu pada unsur kebudayaan sistem organisasi kemasyarakatan serta pencarian hidup. Dimana unsur tersebut memperlihatkan sistem yang dibangun masyarakat dan peran - peran yang dilakukan masyarakat berupa menjadi penjual dan pembeli dengan tujuan pencarian hidup atau memenuhi kebutuhan hidupnya.

b. Aspek Hubungan Sosial

Sedangkan untuk aspek hubungan sosial sangat jelas terlihat dimana masyarakat yang berinteraksi di pasar tradisional yang berlatar belakang profesi yang beragam baik petani, ibu rumah tangga, pedagang, pegawai, nelayan dan profesi lainnya membangun hubungan dalam tujuan pemenuhan hidupnya yang saling berinteraksi langsung antara penjual dan pembeli. Berbeda halnya dengan hubungan sosial yang terjadi di pasar modern seni dari interaksi jual beli antara penjual dan pembeli tidak terjadi karena barang - barang yang diperjualkan sudah ditetapkan harganya. Sehingga dianggap interaksi atau hubungan sosialnya kurang terlihat. Inilah menjadi salah satu seni dalam eksistensi pasar tradisional yang perlu dipertahankan.

c. Aspek Aset Wisata

Tata lokasi yang sederhana diatur dengan tampa menghilangkan gaya klasik sebuah pasar tradisional membuat daya tarik wisata bagi pasar itu sendiri. Transaksi tawar menawar yang mengkhas menjadi obyek sasaran yang kental di pasar tradisional, serta persaingan harga yang masih relative murah yang didasarkan barang - barang yang diperjual belikan merupakan produk yang langsung didatangkan oleh masyarakat tanpa pemprosesan yang lebih lanjut, misalnya hasil pertanian yang baru saja didatangkan dari petaninya langsung, sehingga tingkat harga masih bisa dipengaruhi penawaran dan permintaan kedua pihak (penjual dan pembeli).

Bagi Bapak Sonni, yang merupakan Plt.Kasie Pembukuan secara pribadi menjelaskan bahwa perbandingan pasar tradisional dengan pasar modern yang ada di Buleleng adalah 1 pasar tradisional bersaing dengan 2 sampai dengan lebih pasar modern yang ada dalam satu daerah. Disini yang dimaksud dengan pasar modern adalah minimarket, toko - toko grosir yang kepemilikannya pribadi atau individu. Untuk jumlah pasar tradisional yang ada di Kabupaten Buleleng yaitu berjumlah 18 unit pasar yang terdiri dari:
1) Pasar Anyar Singaraja
2) Pasar Banyuasri
3) Pasar Banjar
4) Pasar Buleleng
5) Pasar Bungkulan
6) Pasar DC Seririt
7) Pasar Kampung Bugis
8) Pasar Kampung Tinggi
9) Pasar Kubutambahan
10) Pasar Latri
11) Pasar Mumbul
12) Pasar Pancasari
13) Pasar Seririt
14) Pasar Sanggalangit
15) Pasar Sukasada
16) Pasar Sangsit
17) Pasar Tamblang
18) Pasar Taman Kota A dan B 
Namun ada lima pasar yang mengalami pengalihan pengelolaan dari semula PD. Pasar menjadi Desa Adat yaitu Pasar Kubutambahan, Pasar Pancasari, Pasar Banjar, Pasar Sanggalangit dan Pasar Sangsit. Dari 15 unit yang dikelola PD.Pasar pendapatan yang disetorkan setiap pasar menjadi pendanaan pasar tradisional selama ini.

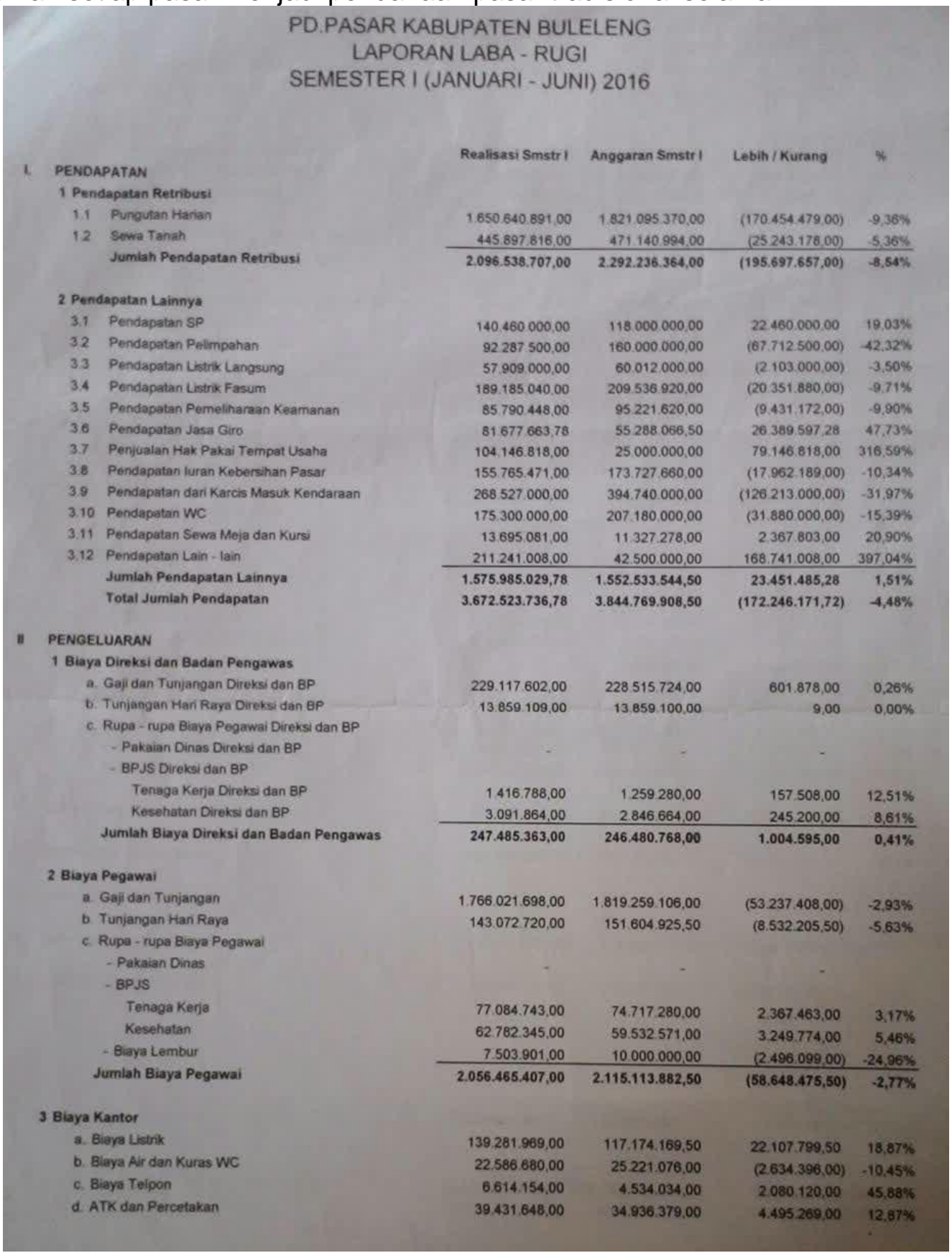

Gambar 1.

Laporan Laba - Rugi PD.Pasar/Sumber: dokumentasi observasi. 
Jurnal IImiah Akuntansi danHumanika, Vol. 8 No. 2, Agustus 2018

ISSN: 2599-2651

\begin{tabular}{|c|c|c|c|c|}
\hline & Realisasi Smstr I & Anggaran Smstr I & Lebih / Kurang & * \\
\hline e. Karcis & $22041.064,00$ & $23,300000,00$ & $(1.258,936,00)$ & $-5,40 \%$ \\
\hline 1. Administrasi Bank dan Bunga & $157,000,00$ & 1.578500 .00 & $(1.421500,00)$ & $90.05 \%$ \\
\hline Jumlah Biaya Kantor & $230.112 .515,00$ & $206.744 .158,50$ & $23.368 .356,50$ & $11,30 \%$ \\
\hline \multicolumn{5}{|l|}{4 Biaya Umum } \\
\hline a. Biaya Bahan Bakar dan Transport & $6.798 .243,00$ & $5.034,000,00$ & $1.764,243,00$ & $35.05 \%$ \\
\hline b. Operasional dan Penertban Pasar & $68.319 .440,00$ & 53.500 .000 .00 & $14.819 .440,00$ & $27,70 \%$ \\
\hline c. Biaya Rapat dan Konsumsi & $6.459,500,00$ & $5.250,000,00$ & $1.209500,00$ & $23.04 \%$ \\
\hline d. Bantuan Desa & $7.273 .674,17$ & $25.535,250,00$ & $(18.261,575,83)-7$ & $-71,526$ \\
\hline C. Perjalanan Dinas Dalam dan Luar Daerah & $22.445,350,00$ & $31,500.000,00$ & $(9.054,650,00)-2$ & $28,74 \%$ \\
\hline 1. Pendidikan dan Pelathan & $\cdot$ & $13.242 .750,00$ & $(13.242 .750 .00)-10$ & $-100.00 \%$ \\
\hline 9. Rupa - rupa Biaya Umum & & $\cdot$ & & \\
\hline Biaya Hari Besar Nasional dan Even-even Daerah & $54,975,104,00$ & $45,000,000,00$ & $9975,104,00$ & $22,17 \%$ \\
\hline Biaya Promosi dan Ikian & - & $5000.000,00$ & $(5,000,000,00)-10$ & $-100,00 \%$ \\
\hline RitualNpacara Keagamaan & 23.216 .200 .00 & $32.500 .000,00$ & $(9.283 .800,00)-2$ & $-28.57 \%$ \\
\hline h Biaya Rumah Tangge & $21.024,701,00$ & $20.617000,00$ & $407.701,00$ & $1,98 \%$ \\
\hline Jumlah Biaya Umum & $210.512 .212,17$ & $237.179 .000,00$ & $(26.666,787,83)$ & $-11,24 \%$ \\
\hline \multicolumn{5}{|l|}{5 Biaya Pemeliharaan } \\
\hline a. Pmi Gedung/Bangunan Pasar & $50.098 .500,00$ & $47,500,000,00$ & $2.598 .500,00$ & $5,47 \%$ \\
\hline b. Pml Kendaraan Dinas dan Inventaris Kantor & 19.889 .981 .00 & $12.500,000,00$ & $7.389981,00$ & $59.12 \%$ \\
\hline c. Pml Instalasi Listrik & $17.575 .000,00$ & 12.500 .000 .00 & $5.075 .000,00$ & $40.60 \%$ \\
\hline Jumlah Biaya Pemeliharaan & $87.563 .481,00$ & $72.500 .000,00$ & $15.063 .481,00$ & $20,78 \%$ \\
\hline \multicolumn{5}{|l|}{6 Biaya Rupa - rupa } \\
\hline \multicolumn{5}{|l|}{ a. Biaya Lain - lain } \\
\hline Pajak 21 & $12.037 .741,00$ & $17.500,000,00$ & $(5.462 .259,00)$ & $-31,21 \%$ \\
\hline - Pajak Final pasal 4 & $38.996 .290,00$ & 47.114 .099 .50 & $(8.117 .809 .50)$ & $-17.23 \%$ \\
\hline - Pajak Jasa Giro dan Tabungan & $6.468,866,73$ & $5.201 .189,00$ & $1.267 .677,73$ & $24,37 \%$ \\
\hline - Pajak Bumi dan Bangunan & - & $7250,000,00$ & $(7.250 .000,00)-1$ & $-100,00 \%$ \\
\hline - Akuntan Publik & - & $13750,000,00$ & $(13.750,000,00)-1$ & $-100,00 \%$ \\
\hline Adipura dan Kebersihan & $67.523 .449,00$ & $10.000 .000,00$ & 57.523 .449 .00 & $575.23 \%$ \\
\hline - Lain- tain & $27.482,300,00$ & 15.000 .000 .00 & 12.482 .300 .00 & $83,22 \%$ \\
\hline Jumlah Biaya Rupa - rupa & $152.508 .646,73$ & $115.815 .288,50$ & $36.693 .358,23$ & $31,68 \%$ \\
\hline Total Jumlah Pengeluaran & $2.984 .647 .624,90$ & $2.993 .833 .097,50$ & $49.463 .002,90$ & $1,65 \%$ \\
\hline UR Sebelum Penyusutan Aktiva Tetap & $687.876 .111,88$ & $850.936 .811,00$ & (163.060.699,12) & $-19,16 \%$ \\
\hline Penyusutan Aktiva Tetap & $(482.529 .093,00)$ & $(459.532 .536,00)$ & $(22.996 .557,00)$ & $5,00 \%$ \\
\hline Laba Bersih Sebelum Pajak & $205.347 .018,88$ & $391.404 .275,00$ & $(186.057 .256,12)$ & $-47,54 \%$ \\
\hline Taksiran Pajak Penghasilan & $(25.668 .377,36)$ & $(48.925 .534,00)$ & $23.257 .156,64$ & $-47,54 \%$ \\
\hline Laba Bersih Setelah Pajak & $179.678 .641,52$ & $342.478 .741,00$ & (162.800.099,48) & $-47,54 \%$ \\
\hline Mengetahuilmenyetujui & Diperiksa oleh & Diteliti oleh & Dibuat oleh & \\
\hline IGde Putu Satwika Yadnya, Msc & It.Dewra Ketut Anom & LMd. Sullistiawan, SE & Komana Sonni. & Ni.SE \\
\hline Direktur Utama & Direktur Keuangan & Kabag Keuangan & Pit.Kasie Pembul & sukuan \\
\hline
\end{tabular}

Gambar 2.

Laporan Laba - Rugi PD.Pasar/Sumber: dokumentasi observasi. 


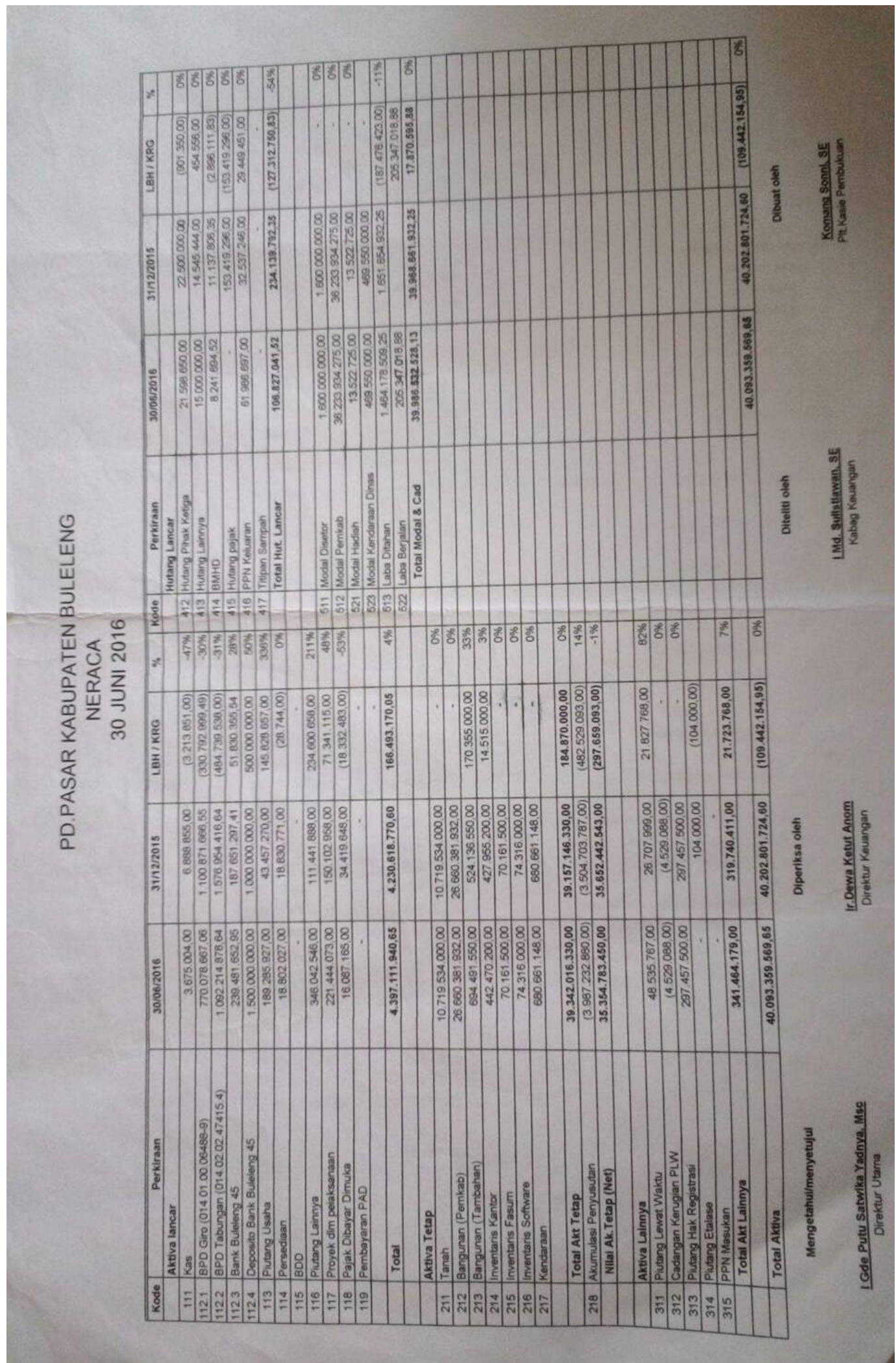

Gambar 3.

Laporan Laba - Rugi PD.Pasar/Sumber: dokumentasi observasi.

\subsection{Tanggapan Masyarakat Terhadap Pasar Tradisional}

Di sini masyarakat sebagai tolak ukur penilain kinerja pemerintahan khususnya pada pengelolaan pasar tardisional. Masyarakat yang di maksud di sini yaitu orang-orang yang kerap bertransaksi di pasar seperti ibu rumah tangga, pedagang-pedagang kecil, dan masih banyak lagi dari berbagai kalangan baik dari muda hingga lansia. 
Penelitian mencakup beberapa lingkup data yang diminta seperti poin pertama identitas responden yang meliputi nama, jenis kelamin, umur, pekerjaan, serta pengunjung pasar. Kemudian pada poin kedua meliputi beberapa pertanyaan yang berbobot setuju(S), sangat setuju(SS), serta kurang setuju(KS). Beberapa pertanyaan yang meliputi pendapat masyarakat lebih suka berbelanja di pasar tradisional atau di pasar modern, persaingan harga atau keterjangkauan harga antara pasar tradisional dengan pasar modern, dan perbandingan fasilitas di pasar tradisional dengan pasar modern. Sedangkan pada poin ketiga merupakan kolom saran responden untuk pengelola pasar. Selanjutnya pada poin keempat meliputi keterangan dan tata cara pengisian questioner. Poin terakhir ialah berupa ulasan tujuan pengadaan questioner oleh peneliti serta ucapan terima kasih peneliti kepada partisipasi masyarakat atau responden.

Dari lima belas (15) pasar tradisional yang ada di Singaraja, kami mengambil contoh tiga (3) seperti di Pasar Kampung Tinggi, Pasar Banyuasri, dan Pasar Anyar. Untuk mengambil data dari masyarakat, kami menyebarkan questioner penelitian. Pada tiga lokasi tersebut kami mengambil 15 sampel di setiap lokasinya. Rata-rata dari masyarakat yang menjadi responden memberikan tanggapan lebih setuju berbelanja di pasar tradisional, pendapat sangat setuju untuk keterjangkauan harga di pasar tradisional, pendapat setuju pada keterjangkauan lokasi pasar tradisional, serta pendapat kurang setuju untuk fasilitas yang ada di pasar tradisional. Dengan pendapat kurang setuju terhadap fasilitas yang ada di pasar tradisional mulai dari fasilitas parker, fasilitas toilet umum, serta fasilitas kebersihan pasar yang dirasa kondisi fasilitas masih kurang sehingga pada saran responden, masyarakat memaparkan:

1. Kebersihan pasar harus ditingkatkan.

2. Penataan dagang harus rapi.

3. Penataan parker perlu diteraturkan.

4. Pengelolaan pasar baik dari fisik dan material perlu diperbaiki sehingga meningkatkan kenyamanan masyarakat dalam berbelanja di pasar tradisional.

5. Penyedia fasilitas toilet umum perlu diperhatikan dan dijaga kebersihannya.

6. Pengaturan selokan sehingga bau tidak sedap tidak terlalu mengusik kenyamanan masyarakat yang berbelanja di pasar tradisional.

Dapat diketahui secara umum masyarakat menilai keberadaan pasar tradisional masih berpotensi dengan keunggulan harga di pasar tradisional yang lebih terjangkau namun keberadaan fasilitas yang ada di pasar tradisional kurang terjaga kebersihannya serta fasilitas yang kurang memadai. Yang menjadi daya banding keberadaan pasar tradisional dengan pasar modern dimana pengadaan dan pemeliharaan pasar tradisional yang kurang dari pasar modern sehingga menjadi tantangan tersendiri bagi pemerintah khususnya PD Pasar mengupayakan perbaikan fasilitas, administrasi, serta tata kelola dalam menjaga eksistensi dari pasar tradisional tersebut.

\subsection{Upaya Pemerintah}

Melihat kondisi persaingan keberadaan pasar tradisional ditengah maraknya pasar modern, menjadi tantangan bagi pemerintah khususnya pengelola pasar tradisional dalam hal ini ialah PD. Pasar Kabupaten Buleleng. Seperti ulasan Bapak Sonny, ditemui tim penelitian di kantor PD.Pasar yang beralamat di Jalan Angrek No.7 Pasar Mumbul Lantai II, Buleleng.Menanggapai keberadaan pasar tradisional yang mulai terancam dengan keberadaan pasar modern, sehingga eksistensi dari pasar tradisional harus dipertahankan dan dikembangkan.

Selain itu untuk menanggapi respon masyarakat mengenai kondisi fisik pasar yang masih kurang baik, adapun upaya yang dilakukan oleh PD.Pasar sendiri meliputi renovasi dan revitalisasi pasar. Menurut Bapak Sonny, "renovasi merupakan perbaikan dan penetaan struktur bangunan fisik pasar yang dilakukan pengajuan oleh pengawas PD.Pasar dimana mempertimbangkan umur dan kelayakan pasar". Sedangkan penjabaran mengenai revitalisasi, menurut beliau merupakan suatu usaha atau upaya perbaikan dalam dua hal 
yaitu bangunan fisik dan penataan pasar (baik berupa lokasi dan penataan pedagang sehingga lebih tertata).

Salah satu kegiatan nyata yang merupakan kegiatan nyata seperti renovasi pasar seririt setelah kebakaran pada tahun 2014 silam dimana penyelesaian yang dirancang sejak tahun 2015 dan terealisasi hingga februari 2016 lalu sehingga operasional pasar dapat berlangsung secara optimal dan kembali normal.

Untuk revitalisasi diupayakan dalam bentuk penataan lokasi aparatur pasar sehingga akses dari pasar lebih mudah, seperti penataan lokasi parkir, lokasi WC umum, pedagang pedagang berdasar komoditi yang diperjual belikan. Tatanan tampilan pasar yang semakin teratur membuat minat pengunjung semakin nyaman dengan kondisi pasar tradisional tersebut. Kenyamanan ditingkatkan dengan perbaikan toilet umum untuk menambah fasilitas.

\section{Simpulan dan Saran}

Pasar tradisional saat ini harus bersaing dengan pasar Modern. Jika tidak dipertahankan secara bik maka mungkin saja pasar tradisional akan disingkarkan oleh pasar modern padahal kontribusi pasar tradisional sangat besar bagi APBD. Kontribusi pasar tradisional terhadap APBD dalam bentuk retribusi seperti uang parkir (karcis kendaraan), sewa tanah, pungutan harian, dan pendapatan lainnya.

Kondisi pasar tradisional saat ini memang sangat memprihatinkan dimana keberadaannya bersaing dengan adanya pasar modern. Terancamnya keberadaan pasar tradisional menjadi dorongan bagi semua pihak baik pemerintah dan seluruh masyarakat untuk melindungi keberadaan pasar tradisional dengan menggali eksistensi yang dimiliki pasar tradisional.

Tanggapan masyarakat terhadap pasar tradisional yaitu masyarakat sebagai tolak ukur penilain kinerja pemerintahan khususnya pada pengelolaan pasar tardisional. Masyarakat yang di maksud di sini yaitu orang-orang yang kerap bertransaksi di pasar seperti ibu rumah tangga, pedagang-pedagang kecil, dan masih banyak lagi dari berbagai kalangan baik dari muda hingga lansia.

Adapun saran-saran yang dapat kami sampaikan adalah sebagai berikut.

1. Bagi penulis, penulisan ini masih perlu diperbaiki lebih jauh sebagai pengembangan ilmu sehingga dapat menjadi pengetahuan bagi masyarakat. Diharapkan untuk ke depannya agar menbuat makalah yang lebih baik dari ini.

2. Bagi pembaca, diharapkan memberikan gambaran yang lebih kritis mengenai mengenai modernisasi tanpa meninggalkan budaya dan karakteristik Indonesia serta tetap memihak rakyat kecil seperti pedagang tradisional.

3. Bagi pemerintah, diharapkan akan adanya regulasi yang memberikan angin segar bagi pasar tradisional yang saat ini kian terpuruk.

\section{DAFTAR PUSTAKA}

Izza, Nahdliyul.2010. Skripsi "Pengaruh Pasar Modern Terhadap Pedagang Pasar Tradisional (Studi Pengaruh Ambarukmo Plaza Terhadap Perekonomian Pedagang Pasar Desa Caturtunggal Nogogaten Depok Seleman Yogyakarta)".Yogyakarta: Universitas Islam Negeri Sunan Klijaga Yogyakarta. Diakses pada Kamis, 1 Desember 2016 pada suka.ac.id/5595/1/BAB\%20I,IV,\%20DAFTAR\%20PUSTAKA.pdf

Prayudi, Made Aristia dan Komang Adi Kurniawan Saputra.2016.Akuntansi Pemerintah.Singaraja:Istiqilal Publishing Group.

Suharsimi, Arikunto.1985. Prosedur Penelitian IImiah : Suatu Pendekatan Praktis. Jakarta: PT.Bina Aksara. 